\title{
Diegetic temporality in libertine literature of the eighteenth century
}

Keywords: diegetic, personalities, pornography, political, eighteenth-century

\section{Short Communication}

The diegetic temporality in French libertine literature is almost contemporaneous at the time when novelists live. On the one hand, the backgrounds and characters described correspond perfectly to those that the authors were able to meet since the narrated events are almost contemporaneous with the writing of libertine writings. On the other hand, libertine authors are interested in the socio-political situation despite traditional discriminatory prejudices such as pornography that consider these authors detached from the changes of the time.

As far as narrated stories are concerned, it is the possibility of guessing which personalities, like Philippe d'Orléans, are hiding behind these fictional names. The libertine novelists then reconstitute some scandals of the time concerning the most famous personalities and the most appreciated actresses. After Galland's French translation of The Thousand and One Nights in 1704, libertine writers try a new literary genre that, first of all, offers them the possibility of retaking the traditional fairy-tale of the seventeenth century in the manner of Perrault, but also of It incorporates the charm of the East. The fairytale gallant comes to the world especially as libertine novelists take the opportunity to reverse this genre to conduct a critique of the French society of their time. The sumptuousness of oriental places is in fact all conventional. Indeed, the fairy tale gives writers the opportunity to describe eighteenth-century France, to mock its corrupt morals and to reflect on the individual freedom that opposes the imprisonment of women in the seraglio and the castration of slaves forced to serve their masters). Thus, the licentious fairy tale between the Regency and the reign of Louis XV draws its inspiration from the unordered conduct of Philippe d'Orléans and his successor Louis XV., ${ }^{1,2}$ One of the first eighteenth-century libertine writings is certainly the story of Godard de Beauchamps' Prince Apprius. This work is interpreted as a pamphlet aimed at the poorly veiled critic of the Duke of Orleans, while other novels such as the History of Pomponius, Roman Knight and the History of Prince Papyrius represent political attacks more obvious. ${ }^{3}$ It is only the first case that refers to the political personalities of the time. Between 1734 (Tanzaï and Neandarné) and 1748 (Les bijoux indiscrets) are published libertine writings focusing attention on an oriental scenario full of eroticism and oddity. It is obvious then that libertine novelists create a fantasy Orient which is only a literary artifice aimed at the social and political criticism of their time: the allusions are only a pretext for leading the most pungent social satire by evoking the folly of the time as well as by questioning the political institutions. ${ }^{4,5}$

In addition, Crebillon uses an exotic decor in Tanzai and Neandarne or The skimmer, Japanese history (1734) to reveal specific political and religious references such as the marriage of King Louis $\mathrm{XV}$ and the quarrel between the Jesuits and Jansenists. The skimmer giving the title to the novel then becomes a subversive metaphor of the papal bull Unigenitus. This one, emitted in 1713 by Pope Clement XI, puts in the pillory one hundred and one of the propositions drawn
Volume 3 Issue I - 2019

\author{
Luisa Messina \\ Department of Physical Sciences and Earth Sciences, University \\ of Palermo, Italy
}

Correspondence: Luisa Messina, Department of Physical Sciences and Earth Sciences, University of Palermo, Italy, Tel +39. 090-676-5074, Email luisamess84@libero.it

Received: February 05, 2018 | Published: January 04, 2019

from the Reflections on the New Testament, Jansenist work written by Father Quesnel, and establishes the expulsion of the Jansenists from the power. ${ }^{6}$ Despite the opposition of the Parliament of Paris, the papal bull was changed into law in 1730. This then determines a considerable religious and political crisis that still mobilizes French public opinion during the publication of Tanzaï (1734). Prince Tanzaï, protagonist of the Eastern tale of Crebillon, can change his destiny provided he succeeds in convincing the high priest Saugrénutio to lick the handle of a skimmer. The corrupt religious, however, is determined to refuse and pronounces before the people a speech in which he manifests all his artificial eloquence. ${ }^{7}$

The novel Les bijoux indiscrets (1748) formally concludes the cycle of parodic libertine writings. Even if Diderot chooses exotic names like Mangoul, Mirzora and Selim, it is clear that these are fictional characters that represent only King Louis XV, his mistress Madame de Pompadour and the Duke of Richelieu. In addition, the spatial references present in the libertine literature are related to eighteenth-century France: the great mosque of Congo, evoked in The indiscreet jewels, is none other than the cathedral of Notre-Dame. ${ }^{8}$

So even if libertine writers abandon oriental fairy tales, they do not give up trying to attack the lascivious habits of the time. In this respect, the novel the peddler (1761) by François-Antoine Chevrier is one of the most significant novels of the eighteenth century that attacks personalities well known in his day. The work introduces readers to a series of scandalous stories about celebrities whose scandals are already more or less notorious for a Parisian public. Chevrier took the opportunity to denigrate his critics that is to say the father Norbert which gives rise to a scandal because of his debauchery; the Marquis de Caraccioli and his soporific works; Chevalier La Morliere, author of an outrageous article to women; the abbot of La Coste shut up in prison because of his fraud; Maubert de Gouvest, who does not know how to maintain secret confidence; the Chevalier de Mouhy and the four volumes of the novel The Delights of Sentiment and its four volumes as heavy as its author; the pieces of Jean-Baptiste Gresset.

Since 1770 there is a libertine literature that is composed of libels, pamphlets, and erotic tales. Most of the gallant production soon becomes a machine of war designed to pillor monarchical despotism. The royal mistress Madame Du Barry is first and foremost the protagonist of many writings such as the Anecdotes on Madame Du Barry and Mairobert's Pidansat, which focus on the sexual appetites of Louis XV. Soon appear other libertine writings such as the 
anonymous Anecdotes on Madame the comtesse du Barry Matches of Madame Du Barry (1775), The private life of Louis XV (1781) of Mouffle d'Angerville which are a plagiarism of the famous Fastes of Louis XV (1782) of Mauvelain. The royal lover is observed in several situations while she strokes the young black servant Zamore, flogs his lady companion and ridicules the impotence of the future Louis XVI. It leads the king to madness by his seduction companies operated in order to squander the royal treasury. It is finally the cause of the death of the king who would have caught smallpox by an infected girl. ${ }^{9}$ Before the Revolution overturned the monarchy, many libertine pamphlets mocking the aristocrats and Queen Marie Antoinette were published contributing to the fatal deception to the monarchy. These writings are notoriously regarded as stories of seduction since the debauched protagonists are still the representatives of the nobility, exhausted by the search for pleasure. On the eve of the Revolution, the figure of Marie Antoinette is the favorite target of the most outrageous pamphlets. The queen is doubly condemned by the authors of these pamphlets: on the one hand, she squanders public money in the same way as the royal mistresses. On the other hand, it synthesizes the three crimes attributed to the Ancien Régime, that is, wealth, debauchery and counterrevolution. The accusations are more and more insidious at a time when the Revolution is making progress. It is obvious then that obscenity becomes a weapon of denunciation against those who incarnate the Old Regime: it is born a personal, passional and sexual war opposing most of the French to Marie Antoinette. ${ }^{7}$ One of the first libels against the queen is entitled The Loves of Charlot and Toinette (1779) as it highlights an adulterous relationship between Marie Antoinette and his brother-in-law, the Count of Artois, male figure in contrast with that of Louis XVI the impotent. Despite the erotic subject, the libel shows a light and gallant tone. As the Revolution approaches, the titles and contents of these protest pamphlets become more explicit. In 1789 appears the French Messaline which establishes Marie-Antoinette as such, that is to say as the new Messaline of France. If this writing still maintains a gallant tone, the following pamphlet The Austrian on a spree or the Royal Orgy ${ }^{10}$ is more virulent because Marie-Antoinette is defined as "a queen catin" because of his meetings with the Count of Artois and the Duchesse de Polignac. The series of outrageous pamphlets is rather long: we then mention the Uterine Fury of Marie Antoinette (1791) where Marie Antoinette compares her different lovers by preferring the Count of Artois. In the same way as the previous libel, the queen is still designated as "catin". We conclude then that "the queens have always hurt". "In The Love Day, or The Last Pleasures of Marie Antoinette, comedy in 3 acts, in prose, represented for the first time in the Temple, August 20, 1792 the Queen is despised because she has replaced the Count of Artois, escaped from France, by La Fayette. Their adulterers also concern other characters like the princess of Lamballe and a certain Dubois

As regards political awareness among libertine novelists, there are some rare references to the political facts of the time among authors such as Crebillon and Chevrier. If libertine writers at first refused to express their political opinion in a clear way, they finally tried to take an obvious stand during the Revolution. In Les Aphrodites a written work in the midst of the Revolution, Nerciat rebuilds a debauched society by remembering the society of the Ancien Régime, while Sade supports the republican efforts in some chapters of La philosophie dans le boudoir. Other writers, however, choose exile. In The Aphrodites Nerciat imagines that a lascivious duchess, become a courtesan during the revolutionary years, is a sect devoted to pleasures in the manner of the Ancien Régime. It is no coincidence that she, plunging into a bathtub, reads a few pages from the libertine works of the century such as Mirabeau's conversion and the anonymous Le Grand-son d'Hercule. This shows nostalgia for a gallant society that has since disappeared because of the Revolution. Sade manifests sometimes ambiguous attitudes towards the Revolution which risk to make vain his numerous patriotic initiatives (the ignorance of his emigrated son, his role of active citizen of the Piques,) making him suspect because of his still moderate and atheistic positions. Sade is then locked in the prisons of Madelonnettes, Carmes, Saint-Laza controversial novel of the time. Until the first half of the eighteenth century the libertine fairy mocked veiled political figures of the time by resorting to a luxurious and anachronistic scenario. The novel The peddler, ${ }^{11}$ however, shows a significant change as Chevrier is one of the first novelists of his time to blame famous personalities in an explicit manner. After 1770 many libertine writings are pamphlets that dare to criticize sometimes the royal mistresses sometimes Queen Marie Antoinette in a more aggressive way as the Revolution advances. ${ }^{12-22}$ finally, the Revolution triggers a finally concrete awareness among libertine novelists by showing different attitudes towards the Revolution. If Sade adheres to revolutionary ideas, Nerciat regrets the society of Ancient Régime while Reveroni Saint-Cyr describes the miserable condition characterizing the emigrant and the horrors of the Revolution.

\section{Acknowledgments}

None.

\section{Conflicts of interest}

The author declares that there are no conflicts of interest

\section{References}

1. Stroev A. The adventurers of the Enlightenment. Paris: PUF; 1997. 349 p.

2. Veysman N. The bowels of the devil. In: Immoral Tales N Veysman, Delon M, editors. Paris: Laffont; 2009. 710 p.

3. Madonia FPA. Ugliness over words: The History of Prince Apprius of Godard de Beauchamp. In: Metamorphoses of ugliness. Legrand MD, Picciola L, editors. Paris Nanterre: Paris X University; 2005. 258 p.

4. Barguillet F. The novel in the eighteenth century. Paris: PUF.1981.256 p.

5. Bernier MA. Libertinage and figures of knowledge. Rhetoric and libertine romance in the France of Enlightenment. Quebec and Paris: Presses of Laval University and L'Harmattan; 2001. 382 p.

6. Andrei C. Eighteenth century libertine novels. Narrative configurations Bucharest: Editura Didactica si pedagogica; 2006. 13 p.

7. Andrei C. Textual Strategies in Enlightenment Discourse. Bucharest: Editura Didactica si pedagogica; 2006. 13 p.

8. Darnton R. The literary underground of the Old Regime. London: Harvard University Press; 1982. 272 p.

9. Pauvert JJ. Introduction to the Loves of Charlot and Toinette. In: Pauvert JJ, editor. Historical anthology of erotic readings, from Sade to Fallières. Paris: Garnier; 1982. 28 p.

10. Anonymous. The Austrian in goguettes or The Royal Orgy. In: Erotic Anthology, The eighteenth century. Lever M, editor. Paris: Laffont; 2003.222 p.

11. Chevrier FA. The peddler, in Romans libertines. Trousson R, editor. Paris: Laffont; 1993. 22 p. 
12. Sade (de). Philosophy in the boudoir. Paris: Gallimard; 1976. 192 p.

13. Delon M. Gothic Machines. Europe: 1984. 240 p.

14. Delon M. Preface to Pauliska. In: Reveroni Saint Cyr JA, editor. Pauliska or the modern perversity. Paris: Desjonquères; 1991: 210 p.

15. Delon M. The principle of delicacy. Libertinage and melancholy in the eighteenth century. Paris: Albin Michel; 2011.

16. Didier B. Writing the Revolution 1789-1799. Paris: PUF; 1989. 29 p.

17. Étiemble R. The French writers and the Revolution. in History of Literatures. Queneau R, editor. Paris: Gallimard, Library of the Pléiade; $1958.883 \mathrm{p}$.

18. Favart CS. Literary Memoirs and Correspondence, Volume II. Paris: Collin; 1808. 25 p.
19. Genand S. The debauchery and history. Politics of seduction at the end of the Ancien Régime. Oxford: Voltaire Foundationl; 2005. 220 p.

20. Hartmann P. The contract and seduction. Essay on amorous subjectivity in the Enlightenment novel. Paris: Champion; 1988. 244 p.

21. Madonia FPA. Images of ugliness in Pauliska between ancient myths and modern terrors. London: Littéraux; 2001. 209 p.

22. Mainil J. Fresques found, half pardoned escapades: manuscripts found in the novel and the fairy tale. The topos of the found manuscript: proceedings of the international conference. In: Herman J, Hallyn F, editor. Paris: Peeters Leuven; 1997. 29 p. 